\title{
Response surface optimization of the cacao criollo fermentation process in the province of Utcubamba, Amazonas-Peru
}

Optimización mediante superficie de respuesta del proceso de fermentación del cacao criollo en la provincia de Utcubamba, Amazonas-Perú

Optimização através da superfície de resposta do processo de fermentação do cacau criollo na província de Utcubamba, Amazonas-Peru

Diner Mori Mestanza ${ }^{1}$ 중 (iD)

Miguel Ángel Barrena Gurbillón ${ }^{2}$ (a) (D)

Segundo Manuel Oliva $\mathrm{Cruz}^{2}$ (a) (D)

Segundo Grimaldo Chavez Quintana ${ }^{1,2^{*}}$ (a) (D)

Rev. Fac. Agron. (LUZ). 2022, 39(1): e223917

ISSN 2477-9407

DOI: https://doi.org/10.47280/RevFacAgron(LUZ).v39.n1.17

\section{Food Technology}

Associate editor: Dra. Gretty Ettiene
${ }^{1}$ Universidad Nacional Toribio Rodríguez de Mendoza de Amazonas, Instituto de Innovación y Desarrollo para el Sector Agrario y Agroindustrial de la Región Amazonas, Calle Higos Urco 350, Chachapoyas, Perú. CP: 01001.

${ }^{2}$ Universidad Nacional Toribio Rodríguez de Mendoza de Amazonas, Instituto de Instituto de Investigación para el Desarrollo de Ceja de Selva. Calle Higos Urco 350, Chachapoyas, Perú. CP: 01001.

Received: 08-04-2021

Accepted: $15-09-2021$

Published: 16-02-2022

\section{Keywords:}

Fermentation index

Native cocoa

Fine aroma

Theobroma cacao

\begin{abstract}
The fermentation process of native fine aroma cacao criollo (Theobroma cacao) in the province of Utcubamba, Amazonas, Peru, was optimized. A Box-Behnken statistical design was applied, whose factors were inoculum concentration, fermentation time and inoculation sequence. With the optimized model, a phenolic content of 12.99 mg AGE.g ${ }^{-1}$ cocoa, a fermentation index of 1.05 , and theobromine and caffeine contents of 4.89 .100 $\mathrm{g}^{-1}$ cocoa and $1.81 .100 \mathrm{~g}^{-1}$ cocoa, respectively, were obtained. Additionally, with a panel of nine certified and accredited tasters, the basic and special descriptive qualitative sensory attributes of the fermented and dry cocoa beans were determined, obtaining a maximum quality score of 71.1, and the sensory descriptors floral, fruity, nutty, sweet, bitter, acidity and adequate astringency were identified. In the cocoa obtained with the best treatment, 64 volatile compounds from the families of aldehydes, ketones, alcohols, esters, acids and pyrazines were identified by gas chromatography coupled to a mass detector with solid-phase microextraction (GC-MS-SPME-HS). In conclusion, it was possible to optimize the fermentation process of cacao criollo to obtain cocoa with high functional and sensory properties.
\end{abstract}




\section{2-8 $\mid$ Rev. Fac. Agron. (LUZ). 2022, 39(1): e223917. January - March. ISSN 2477-9407.}

\section{Resumen}

Se optimizó el proceso de fermentación de cacao (Theobroma cacao) criollo nativo fino de aroma en la provincia de Utcubamba, Amazonas, Perú. Se aplicó un diseño estadístico de Box-Behnken cuyos factores fueron la concentración de inóculo, tiempo de fermentación y secuencia de inoculación. Con el modelo optimizado se obtuvo un contenido fenólico de $12,99 \mathrm{mg}$ AGE. $\mathrm{g}^{-1}$ cacao, un índice de fermentación de 1,05, contenidos de teobromina y cafeína de $4,89.100 \mathrm{~g}^{-1}$ cacao y $1,81.100 \mathrm{~g}^{-1}$ cacao, respectivamente. Adicionalmente, con un panel de nueve catadores certificados y acreditados, se determinaron los atributos sensoriales básicos y especiales descriptivos cualitativos del cacao en grano fermentado y seco, obteniendo una puntuación de calidad máxima de 71,1 y se identificaron los descriptores sensoriales, floral, frutal, nuez, dulce, amargo, acidez y astringencia adecuada. En el cacao obtenido con el mejor tratamiento, se identificaron 64 compuestos volátiles de las familias de aldehídos, cetonas, alcoholes, ésteres, ácidos y pirazinas, mediante cromatografía de gases acoplada a un detector de masas con micro extracción en fase sólida (GC-MS-SPME-HS). En conclusión, se logró optimizar el proceso de fermentación de cacao criollo que permite obtener cacao con elevadas propiedades funcionales y sensoriales.

Palabras clave: Índice de fermentación, cacao nativo, cacao criollo, Theobroma cacao.

\section{Resumo}

O processo de fermentação do cacau criollo nativo de aroma fino (Theobroma cacao) na província de Utcubamba, Amazonas, Peru, foi otimizado. Um projeto estatístico Box-Behnken foi aplicado com concentração de inóculos, tempo de fermentação e seqüência de inoculação como fatores. Com o modelo otimizado, foi obtido um conteúdo fenólico de 12,99 mg de cacau AGE.g ${ }^{-1}$, um índice de fermentação de 1,05 , teobromina e cafeína de $4,89,100 \mathrm{~g}^{-1}$ de cacau e $1,81,100 \mathrm{~g}^{-1}$ de cacau, respectivamente. Além disso, com um painel de nove provadores certificados e credenciados, foram determinados os atributos sensoriais básicos e os atributos descritivos qualitativos especiais das amêndoas de cacau fermentadas e secas, obtendo-se uma pontuação máxima de qualidade de 71,1 e foram identificados os descritores sensoriais florais, frutados, frutos secos, doces, amargos, acidez e adstringência. No cacau obtido com o melhor tratamento, 64 compostos voláteis das famílias de aldeídos, cetonas, álcoois, ésteres, ácidos e pirazinas foram identificados por cromatografia gasosa acoplada a um detector de massa com microextração de fase sólida (GC-MS-SPME-HS). Em conclusão, foi possível otimizar o processo de fermentação do cacau criollo para obter cacau com altas propriedades funcionais e sensoriais.

Palavras-chave: Índice de fermentação, cacau nativo, cacau criollo, Theobroma cacao.

\section{Introduction}

Among the different processes that cocoa beans must go through (Theobroma cacao), fermentation is the first step in the chocolate chain (De Melo et al., 2013) this process is important and beneficial for the development of sensory characteristics. Microbial activity in cocoa beans removes the mucilage and induces a set of internal biochemical reactions in the cotyledon, which modify the chemical composition of the bean and initiate the formation of aroma precursors. During fermentation, microbial succession is produced by the variation of temperature, $\mathrm{pH}$, oxygen availability and the compounds generated (Kongor et al., 2016), which makes the results very heterogeneous, so the optimization of this process will enhance and preserve the bromatological and organoleptic characteristics of cocoa that guarantees a good quality and homogeneous product (Sandhya et al., 2016).

According to Wacher (2011), yeasts and bacteria (lactic and acetic) are responsible for the fermentation of cocoa pulp, which contains carbohydrates (glucose, fructose and sucrose) at a $\mathrm{pH}$ between 3.3 and 4.0. They indicate that it is also necessary the presence of citric acid, appropriate medium for the development and proliferation of microorganisms that are essential for the transformation of cocoa beans; on the other hand, the production of acetic acid, ethanol and the increase of temperature, avoid the damage of the cocoa bean preventing the enzymatic action. .

The indicator of an optimal fermentation process is the "fermentation index" which must be equal to or higher than one (1) (León-Roque et al., 2016). In this sense, works have been carried out that have sought to improve this indicator using starter cultures that increase the efficiency of fermentation. In this regard, Cempaka et al. (2014), reported the increase of the fermentation index from 0.84 to 1.13 by initial addition of yeast, and Kresnowati et al. (2013) observed that by employing a starter culture composed by yeast and lactic acid bacteria, the fermentation index is improved from 0.86 to 0.95 . Therefore, the objective of this work was to optimize the fermentation process of native fine aroma cacao criollo in the province of Utcubamba, Amazonas, Peru, by means of a response surface.

\section{Materials and methods}

The cocoa samples were acquired in slime from the La Cruz sector of the Cajaruro district, province of Utcubamba, Amazonas, Peru, a native (cacao criollo) producing area of the so-called fine aroma (common in northeastern Peru), characterized by an average altitude of $490 \mathrm{~m}$ above sea level, an average temperature of $29{ }^{\circ} \mathrm{C}$ and humidity of $61 \%$.

The samples were transported in polypropylene bags to the facilities of the Cooperativa Central de Productores Agropecuarios de Amazonas (CEPROAA), where the fermentation experiment was carried out in cubic boxes of laurel wood (Cordia alliodora), $30 \mathrm{~cm}$ on each side, with $20 \mathrm{~kg}$ of cocoa in slime for each treatment. After the fermentation process (according to treatments), the fermented cocoa was dried in the sun until a moisture content of less than $7 \%$ was obtained, then it was packaged in airtight polyethylene bags and transferred to Laboratorio de Control de Calidad de Cacao of Universidad Nacional Toribio Rodríguez de Mendoza de Amazonas, for further analysis.

\section{Obtaining the starter culture}

The procedure described by Ausubel et al. (1989) was followed. For this purpose, pure cultures (yeasts + lactic acid bacteria [BAL] + acetic acid bacteria $[\mathrm{BAA}]$ ) were isolated and biomass was obtained, achieving a frank development of yeasts in $250 \mathrm{~mL}$ flasks with liquid YPD culture medium prepared from meat peptone $\left(20\right.$ g.L $\left.\mathrm{L}^{-1}\right)$, yeast extract $\left(10\right.$ g.L. $\left.\mathrm{L}^{-1}\right)$ and glucose/dextrose $\left(20\right.$ g.L $\left.\mathrm{L}^{-1}\right)$ in ultra-pure water (Ausubel et al., 1989); the medium contained chloramphenicol for bacterial growth inhibition. For lactic and acetic acid bacteria, MRS 
and Acetobacter broths were used. During fermentation, removal or turning was carried out every $24 \mathrm{~h}$, until completing the programmed time according to the treatment.

Determination of the fermentation index (IF)

The IF was determined following the spectrophotometric method described by Gourieva \& Tserevitinov (1979), given by the ratio of absorbances between 460 and $530 \mathrm{~nm}$.

\section{Determination of total phenol content}

The determination of total phenols was carried out using the Folin Ciocalteu assay, for which, a standard calibration curve was prepared from dilutions of 0 to $16 \mathrm{mg} . \mathrm{L}^{-1}$ of gallic acid (Sigma Aldrich, Germany), following the procedure described by Pantelidis et al. (2007). Zero point zero five milliliters $(0.05 \mathrm{~mL})$ of cocoa extract and $0.45 \mathrm{~mL}$ of water with $2.5 \mathrm{~mL}$ of Folin-Ciocalteu reagent (Merck, Germany) diluted 1:10, followed by two (2) $\mathrm{mL}$ of $\mathrm{Na}_{2} \mathrm{CO}_{3}$ at $7.5 \%$ $(\mathrm{m} / \mathrm{v})$; then, they were completely mixed for 10 seconds in Vortex. It was incubated in an oven at $50{ }^{\circ} \mathrm{C}$ for five (5) min, subsequently; the absorbance was measured at $765 \mathrm{~nm}$ in a spectrophotometer (UVVisible S2100 UVTE, ÚNICO).

\section{Determination of theobromine and caffeine}

Theobromine and caffeine were determined by high performance liquid chromatography (HPLC) following the method described by Brunetto et al. (2007), using a chromatograph (Hitachi-Chromaster, Tokyo, Japan, (LC-20AD), equipped with an autoinjector (SIL20A/HT), a communication module (CBM-20A) and a detector with photodiode array (PDA, SPD-M20A), ultraviolet detection was recorded at $278 \mathrm{~nm}$. The separation was carried out on a 5 $\mu \mathrm{m}$ Supelco-LiChrospher RC C-18 column (25 cm x $4.6 \mathrm{~mm})$. A methanol/water mixture $(30: 70 \mathrm{v} / \mathrm{v})$ was used as mobile phase in isocratic mode at a flow rate of $1.0 \mathrm{~mL} \cdot \mathrm{min}^{-1}$. The identification of the signals was performed by comparing the retention times obtained with theobromine and caffeine standards (98\% Sigma-Aldrich, USA). For the quantification of the concentrations of theobromine and caffeine in the cocoa samples, a calibration curve was prepared for theobromine and caffeine in a range from 5 to $100 \mathrm{mg} . \mathrm{L}^{-1}$, with whose areas under the curve the respective linear function was obtained.

\section{Determination of the $\mathrm{pH}$ of cocoa beans}

The $\mathrm{pH}$ of the samples was measured following the methodology described by Senanayake et al. (1999).

Preparation of samples for sensory analysis and volatile compounds

The whole, fermented and dried beans obtained according to the treatments were roasted in a laboratory roaster (IMSA, Peru) of one (1) $\mathrm{kg}$ capacity at $120^{\circ} \mathrm{C}$ for $15 \mathrm{~min}$. Then, they proceeded to shelling in a sheller (IMSA, Peru). The nibs obtained were subjected to a conching process for $4 \mathrm{~h}$ at $50{ }^{\circ} \mathrm{C}$, molded into $50 \mathrm{~g}$ tablets, packed in aluminum foil and polyethylene bag with hermetic seal. The tablets were stored frozen until further analysis.

\section{Sensory analysis of cocoa pastes}

The fermented cocoa according to treatment was dried and processed into paste. Then, with nine (9) judges certified and accredited by APPCacao-Sineace-Minedu-Peru, the basic and special sensory attributes (cocoa flavor, floral, fruity, nutty, sweet, bitter, acidity and astringency) were evaluated with the ordinal scale from 1 to 100 for the total score, given by the sum of the partial scores of each attribute, using the Tasting Card for the sensory analysis of cocoa (USAID, Equal Exchange and TCHO, 2018).

Identification of the volatile compounds in cocoa paste

Volatile compounds were identified using gas chromatography coupled to a mass detector and headspace-micro solid-phase extraction (GC-MS-SPME-HS) (Rodriguez-Campos et al., 2012), employing a divinylbenzene/carboxen/polydimethylsiloxane fiber (DVB/CAR/PDMS), 50/30 $\mu \mathrm{m}$ thick and helium as carrier gas. In $20 \mathrm{~mL}$ vials, $5.7 \mathrm{~g}$ of cocoa paste was placed, six (6) $\mathrm{mL}$ of ultrapure water was added and hermetically sealed with a metallic lid and a $20 \mathrm{~mm}$ white silicone septa. The SPME extraction conditions were: 15 minutes of equilibrium at $50{ }^{\circ} \mathrm{C}$, with an exposure of the fiber for $30 \mathrm{~min}$ at the same temperature. After the extraction time, the fiber was retracted and immediately inserted into the injection port of the gas chromatograph-mass spectrometer (GC-MS) (Angilent technologies, $6890 \mathrm{~N}$, United States), where it was kept for five (5) $\mathrm{min}$ at $250{ }^{\circ} \mathrm{C}$ temperature. Between each extraction a run of the fiber blank (clean-up) was performed for $55 \mathrm{~min}$. For the identification of the compounds, the NIST 14.L library was used.

\section{Experimental design and statistical analysis}

The Box-Behnken statistical design (Murali et al., 2000) was used to determine the best concentration values of inoculum X1 $(1.0 ; 1.8$ and $2.6 \times 10^{3} \mathrm{UFC}_{\mathrm{mL}}^{-1}$ ), inoculation sequence X2 (yeasts + BAL $+\mathrm{BAA}$ at the beginning; yeasts and BAL at the beginning+ BAA at $48 \mathrm{~h}$; yeasts at the beginning + BAL at $24 \mathrm{~h}+\mathrm{BAA}$ at $48 \mathrm{~h}$ ), and fermentation time $\mathrm{X} 3$ (5, 6 and 7 days), as shown in table 1. The responses of interest were the fermentation index (IF), chemical characteristics (total phenols, theobromine, caffeine and $\mathrm{pH}$ ), sensory characteristics and volatile compounds.

Table 1. Box-Behnken arrangement for optimization.

\begin{tabular}{cccc}
\hline Number & \multicolumn{3}{c}{ Variables } \\
\hline Experiment & X1 & X2 & X3 \\
\hline 1 & 0 & - & - \\
2 & + & - & 0 \\
3 & 0 & 0 & 0 \\
4 & 0 & - & + \\
5 & - & 0 & + \\
6 & 0 & + & + \\
7 & - & 0 & - \\
8 & - & - & 0 \\
9 & 0 & 0 & 0 \\
10 & 0 & 0 & 0 \\
11 & + & + & 0 \\
12 & - & + & 0 \\
13 & 0 & + & - \\
14 & + & 0 & + \\
15 & + & 0 & - \\
\hline
\end{tabular}

+: Upper level of the variables, 0: Average level of the variable. -: Lower level of the variables, X1: Inoculum concentration. X2: sequence of inoculation, X3: days of fermentation

Cocoa beans in slime were placed in the fermenters and $10 \mathrm{~mL}$ of the microorganisms were inoculated according to the treatments described. To obtain the optimum fermentation parameters with cocoa starter culture, under the Box Behnken design. A response surface analysis was performed using Minitab 19 software. The Kruskal Wallis non-parametric test was also applied to compare treatments according to sensory qualification. 
4-8 Rev. Fac. Agron. (LUZ). 2022, 39(1): e223917. January - March. ISSN 2477-9407.

\section{Results and discussion}

Table 2 shows the average values of chemical properties of fermented cocoa beans, in which a variation is observed due to the set of reactions generated in the fermentation process, accentuating some characteristic flavors and aromas of the samples, as described by Castro-Alayo et al. (2019).

\section{Optimization of fermentation parameters}

Table 3 shows the optimized values, obtaining an IF higher than $1, \mathrm{pH}$ of 5.32, indicating an adequate fermentation, free of undesirable compounds or acids in the cocoa beans.

Table 2. Chemical properties of fermented cocoa.

\begin{tabular}{cccccc}
\hline Treatments & $\begin{array}{c}\text { Total phenols } \\
\left(\mathrm{mg} \mathrm{GAE} . \mathrm{g}^{-1}\right)\end{array}$ & $\begin{array}{c}\text { Fermentation } \\
\text { index }\end{array}$ & $\mathrm{pH}$ & $\begin{array}{c}\text { Theobromine } \\
\left(\mathrm{g} .100 \mathrm{~g}^{-1}\right. \\
\text { cocoa) }\end{array}$ & $\begin{array}{c}\text { Caffeine } \\
\left(\mathrm{g} .100 \mathrm{~g}^{-1}\right. \\
\text { cocoa })\end{array}$ \\
\hline \hline T1 & $15.07 \pm 0.39$ & $0.68 \pm 0.10$ & $5.85 \pm 0.10$ & 5.04 & 2.47 \\
T2 & $15.57 \pm 0.11$ & $0.71 \pm 0.08$ & $5.82 \pm 0.05$ & 4.93 & 2.31 \\
T3 & $15.46 \pm 0.42$ & $0.90 \pm 0.42$ & $5.78 \pm 0.10$ & 4.58 & 2.04 \\
T4 & $13.78 \pm 0.32$ & $0.95 \pm 0.04$ & $5.65 \pm 0.10$ & 5.07 & 2.23 \\
T5 & $20.41 \pm 0.66$ & $0.55 \pm 0.28$ & $5.69 \pm 0.11$ & 5.13 & 2.15 \\
T6 & $15.23 \pm 0.21$ & $0.78 \pm 0.11$ & $5.86 \pm 0.10$ & 5.06 & 2.06 \\
T7 & $16.93 \pm 0.17$ & $0.99 \pm 0.09$ & $5.59 \pm 0.03$ & 5.12 & 2.25 \\
T8 & $16.73 \pm 0.27$ & $0.99 \pm 0.09$ & $5.63 \pm 0.02$ & 5.65 & 2.68 \\
T9 & $15.46 \pm 0.42$ & $0.90 \pm 0.19$ & $5.74 \pm 0.09$ & 4.96 & 2.48 \\
T10 & $15.46 \pm 0.42$ & $0.90 \pm 0.19$ & $5.70 \pm 0.09$ & 4.92 & 1.92 \\
T11 & $13.93 \pm 0.86$ & $0.97 \pm 0.02$ & $5.80 \pm 0.04$ & 5.81 & 2.35 \\
T12 & $12.17 \pm 0.17$ & $1.25 \pm 0.19$ & $5.17 \pm 0.05$ & 5.00 & 2.05 \\
T13 & $17.28 \pm 0.48$ & $0.87 \pm 0.19$ & $5.33 \pm 0.09$ & 6.14 & 2.46 \\
T14 & $12.90 \pm 0.66$ & $1.05 \pm 0.15$ & $5.32 \pm 0.06$ & 4.98 & 1.78 \\
T15 & $15.37 \pm 0.41$ & $1.18 \pm 0.09$ & $5.27 \pm 0.10$ & 5.65 & 2.40 \\
\hline
\end{tabular}

Table 3. Response and optimized values for chemical properties of the native fine aroma cocoa samples.

\begin{tabular}{lccc}
\hline \multicolumn{1}{c}{ Response } & Optimized & $\begin{array}{c}<95.0 \\
\%\end{array}$ & $\begin{array}{c}>95.0 \\
\%\end{array}$ \\
\hline Total phenols (mg GAE. $\left.{ }^{-1}\right)$ & 12.99 & 7.80 & 18.19 \\
Fermentation index & 1.05 & 0.57 & 1.52 \\
pH & 5.32 & 4.97 & 5.67 \\
$\begin{array}{l}\text { Theobromine concentration } \\
\text { (g.100 g } \mathrm{g}^{-1} \text { cocoa) }\end{array}$ & 4.89 & 4.44 & 5.35 \\
$\begin{array}{l}\text { Caffeine concentration (g.100 g-1 } \\
\text { cocoa) }\end{array}$ & 1.81 & 1.37 & 2.25 \\
\hline
\end{tabular}

The optimized model was determined: inoculum concentration $2.6 \times 10^{3}$ UFC. $\mathrm{mL}^{-1}$, yeast inoculation sequence and BAL at the beginning $+\mathrm{BAA}$ at $48 \mathrm{~h}$ and fermentation time ( 7 days), to achieve an adequate fermentation process (figure 1).

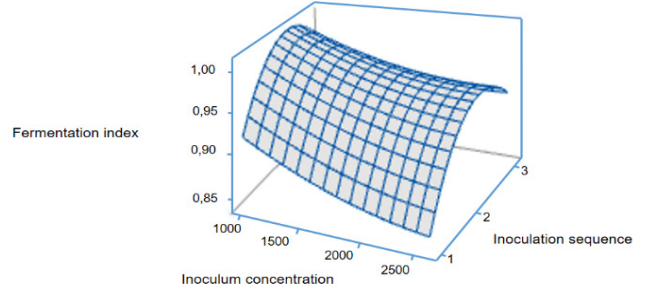

Figure 1. Response surface graph to optimize the fermentation index in the fermentation process of cacao criollo.

The optimized model (figure 2), allows to obtain fermented cocoa with low levels of total phenols (12.99 AGE. $\left.\mathrm{g}^{-1}\right)$, therefore the pastes have low astringency (Ooi et al., 2020). Given the differences in the results, treatments 7, 8 and 11, due to their high fermentation index (table 2), improved microbial activity, they were able to hydrolyze free, soluble phenolic complexes, which are easily absorbed, leading to a decrease in seeds (Haile \& Kang, 2019; Jalil \& Ismail, 2008). This has been largely attributed to oxidation of insoluble tannins and leaching of almonds polyphenols into the surrounding pulp and subsequent runoff on sweating (Wollgast \& Anklam, 2000).

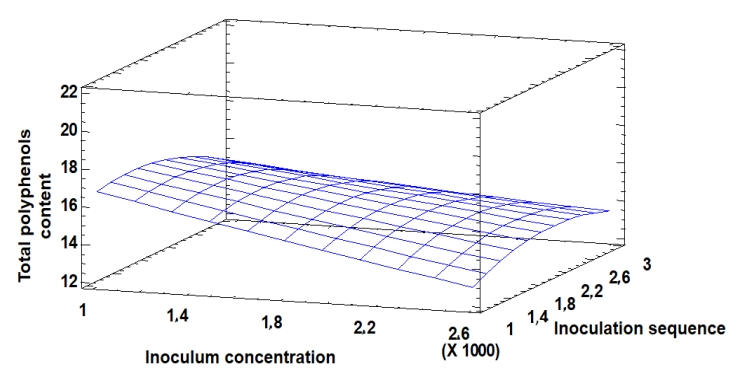

Figure 2. Response surface graph to optimize the phenolic content in the fermentation process of cacao criollo.

The application of the microorganisms allowed to obtain a fermentation index equal to 1.05 in seven (7) days, very consistent results due to the obtaining of completely fermented beans with well pronounced, light brown to dark brown striations (Ooi et al., 2020). It should be noted that the brown color formed is due to the oxidation reaction when catalyzing o-diphenol to o-quinone (Hernández-Hernández et al., 2016).

The model allowed to obtain an optimized $\mathrm{pH}$ value of 5.32; which indicates an adequate fermentation process, the $\mathrm{pH}$ of beans leads to the generation of more free peptides and amino acids, which would be able to form the Maillard reaction during roasting, contributing to more preferred aroma and flavor notes (Afoakwa $e t$ al., 2008; John et al., 2019).

\section{Theobromine and caffeine concentrations}

The optimal values of theobromine and caffeine were 4.89 and 1.81 g. $100 \mathrm{~g}^{-1}$ cocoa respectively; values that indicate the intensity of bitterness in the cocoa paste (Brunetto et al., 2007), these compounds are associated with the index fermentation of cocoa beans (Cardoso et al., 2020). 
Sensory analysis of native fine cacao criollo paste with fermented aroma with different treatments

Figure 3 shows the results obtained in the sensory analysis of the quality attribute of native fine aroma cocoa.
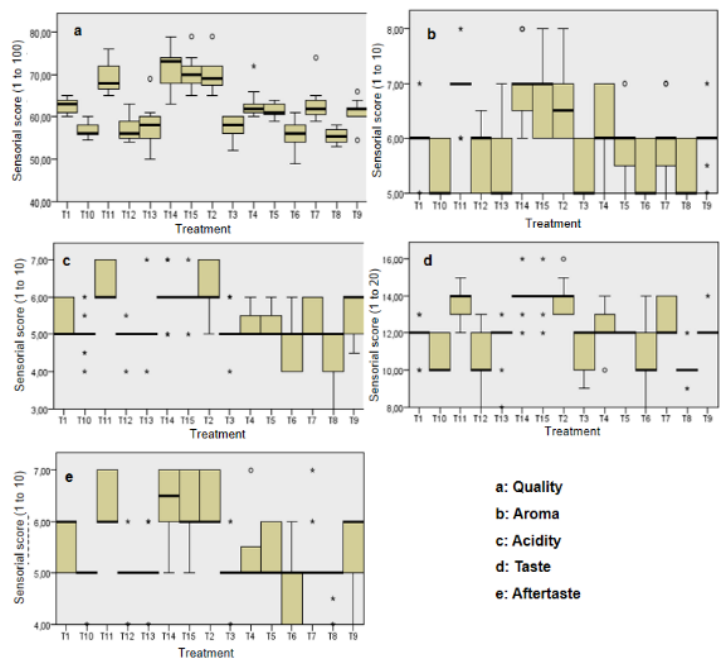

Figure 3. Sensory analysis of the quality attribute of native fine aroma cocoa.

Four treatments (T11, T14, T15 and T2) formed the best scored group (close to 70) in terms of quality of the cocoa paste obtained per treatment, as shown in figure $3 \mathrm{a}$.
The same treatments that allowed obtaining higher quality were those that obtained the best aroma score, as shown in figure 3b. Average scores of seven (7) for treatments 11, 14 and 15, evidence that the fermentation was adequate and that the volatile compounds precursors of the aroma were enhanced. Fermentation treatments 11, 14, 15, 2 and 9, obtained the best scores in sensory acidity. The judges revealed a citric acidity, this could be due to 4-methylpentanoic and beta-myrcene acids, identified in T14, the treatment with the highest sensory acceptance $(\mathrm{p}<0.05)$, as can be seen in Figure $3 c$, which confer an acidity similar to a sweet orange, generated and transferred to the cotyledons during the fermentation process, being this type of acidity beneficial for special cocoa samples (Utrilla-Vázquez et al., 2020). The same treatments had the highest scores in flavor and aftertaste (figures $3 \mathrm{~d}$ and $3 \mathrm{e}$ ).

Identification of the volatile compounds of native fine aroma cocoa

The volatile compounds precursors of aroma were identified in treatment 14 (table 4), due to it was the best treatment. Among the identified volatile compounds, aldehydes, ketones, alcohols, esters, acids and pyrazines, mainly responsible for special aromas and flavors, such as Linalool, 2-Nonanol (floral, menthol, cinnamon, citrus and fruit aromas); 3-ethyl-2,5-dimethyl pyrazine, tetramethyl pyrazine, 2-ethyl-6-methyl pyrazine, trimethyl pyrazine, 2,3,5-trimethyl-6-ethylpyrazine (aromas of roasted cocoa, sweet panela, sweet caramel) (Utrilla-vázquez et al. , 2020). Figure 4 shows chromatogram of volatile compounds identified by GC-MSSPME-HS.

Table 4. Volatile compounds identified in fermented samples of native fine aroma cacao criollo.

\begin{tabular}{|c|c|c|c|c|}
\hline Compound name & Group & Chemical formula & TR & Compound aroma description*. \\
\hline Dimethyl ether & Ether & $\mathrm{C}_{2} \mathrm{H}_{6} \mathrm{O}$ & 4.855 & Fruits \\
\hline Acetone & \multirow{2}{*}{ Aldehydes and ketones } & $\mathrm{C}_{3} \mathrm{H}_{6} \mathrm{O}$ & 5.475 & Fruits \\
\hline 2-Methylpropanal & & $\mathrm{C}_{4} \mathrm{H}_{8} \mathrm{O}$ & 7.096 & Sweet \\
\hline Acetic acid & Acid & $\mathrm{C}_{2} \mathrm{H}_{4} \mathrm{O}_{2}$ & 7.625 & Bitter, vinegar \\
\hline 2,3-Butanedione & \multirow{2}{*}{ Ketones } & $\mathrm{C}_{4} \mathrm{H}_{6} \mathrm{O}_{2}$ & 7.943 & Buttery \\
\hline 2-Butanone & & $\mathrm{C}_{4} \mathrm{H}_{8} \mathrm{O}$ & 8.194 & Sweet \\
\hline Butanimidamide & & $\mathrm{C}_{4} \mathrm{H}_{10} \mathrm{~N}_{2}$ & 10.688 & $\cdots$ \\
\hline 2-Methylbutanal & Aldehydes and ketones & $\mathrm{C}_{5} \mathrm{H}_{10} \mathrm{O}$ & 11.108 & Malt, chocolate \\
\hline 2,3-Pentanedione & Ketones & $\mathrm{C}_{5} \mathrm{H}_{8} \mathrm{O}_{2}$ & 12.345 & Toasted almond, cocoa, yogurt, nuts \\
\hline Pentanal & Aldehydes and ketones & $\mathrm{C}_{5} \mathrm{H}_{10} \mathrm{O}$ & 12.541 & Fruits \\
\hline Acetoin & Aldehydes and ketones & $\mathrm{C}_{4} \mathrm{H}_{8} \mathrm{O}_{2}$ & 12.982 & Butter \\
\hline \multirow[t]{2}{*}{$\begin{array}{l}\text { 3-(1methylethyl)oxoethane } \\
\text { 2-Methylpropanoic acid }\end{array}$} & & $\mathrm{C}_{6} \mathrm{H}_{12} \mathrm{O}$ & 14.283 & $\ldots$ \\
\hline & Acid & $\mathrm{C}_{4} \mathrm{H}_{8} \mathrm{O}_{2}$ & 14.515 & $\cdots$ \\
\hline 2,3-Butanediol & Alcohol & $\mathrm{C}_{4} \mathrm{H}_{10} \mathrm{O}_{2}$ & 16.446 & $\ldots$ \\
\hline Cyclobutanol, 2-ethyl & & $\mathrm{C}_{6} \mathrm{H}_{12} \mathrm{O}$ & 17.664 & $\cdots$ \\
\hline Hexamethyl cyclotrisiloxane & & $\mathrm{C}_{6} \mathrm{H}_{18} \mathrm{O}_{3} \mathrm{Si}_{3}$ & 18.061 & $\cdots$ \\
\hline 3-Furaldehyde & Aldehydes and ketones & $\mathrm{C}_{5} \mathrm{H}_{4} \mathrm{O}_{2}$ & 19.34 & Toasted almond \\
\hline Butanoic acid, 2-methyl & Acid & $\mathrm{C}_{5} \mathrm{H}_{10} \mathrm{O}_{2}$ & 19.477 & $\cdots$ \\
\hline 3-Furanmethanol & Alcohol & $\mathrm{C}_{5} \mathrm{H}_{6} \mathrm{O}_{2}$ & 20.166 & Mint \\
\hline 2-Heptanone & Aldehydes and ketones & $\mathrm{C}_{7} \mathrm{H}_{14} \mathrm{O}$ & 22.094 & Fruit, plantain \\
\hline Styrene & & $\mathrm{C}_{8} \mathrm{H}_{8}$ & 22.656 & Sweet, cinnamon, coffee. \\
\hline 1-(2-Furanyl) ethanone & & $\mathrm{C}_{6} \mathrm{H}_{6} \mathrm{O}_{2}$ & 23.214 & $\ldots$ \\
\hline
\end{tabular}

*(Utrilla-vázquez et al., 2020). 
6-8 | Rev. Fac. Agron. (LUZ). 2022, 39(1): e223917. January - March. ISSN 2477-9407.

Table 4. Volatile compounds identified in fermented samples of native fine aroma cacao criollo (continuation).

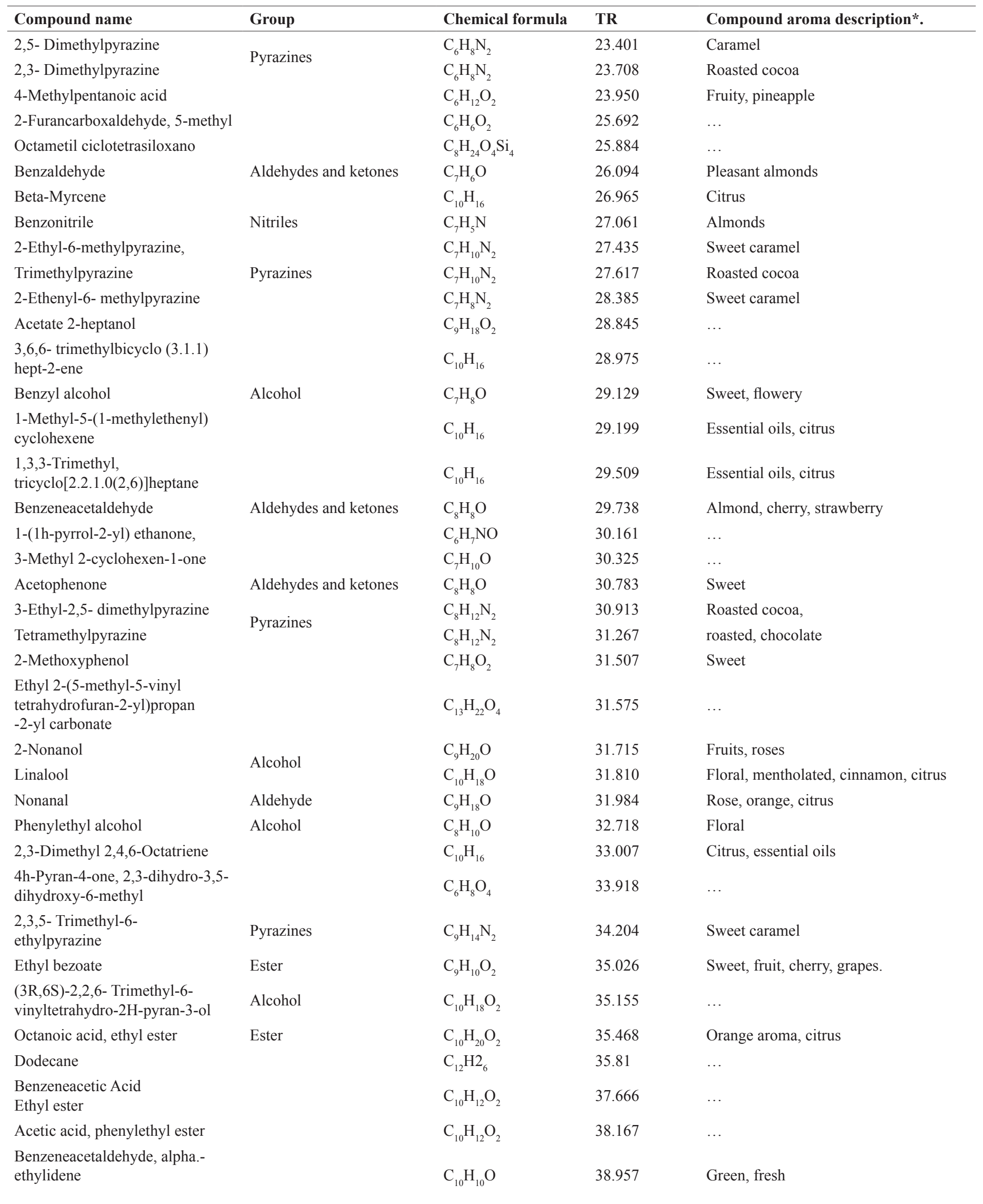

*(Utrilla-vázquez et al., 2020). 
Table 4. Volatile compounds identified in fermented samples of native fine aroma cacao criollo (continuation).

\begin{tabular}{|c|c|c|c|}
\hline Compound name & Chemical formula & TR & Compound aroma description*. \\
\hline Cyclotetradecane & $\mathrm{C}_{14} \mathrm{H} 2_{8}$ & 42.865 & $\ldots$ \\
\hline 1-Butanol, 3-methyl-, benzoate & $\mathrm{C}_{12} \mathrm{H}_{16} \mathrm{O}_{2}$ & 43.289 & $\ldots$ \\
\hline 5-Methyl-2-phenyl-2-hexenal & $\mathrm{C}_{13} \mathrm{H}_{16} \mathrm{O}$ & 46.478 & Cocoa \\
\hline $\begin{array}{l}\text { 1H-2-Benzopyran-1-one, } \\
\text { 3,4-dihydro- 8-hydroxy-3-methyl }\end{array}$ & $\mathrm{C}_{10} \mathrm{H}_{10} \mathrm{O}_{3}$ & 48.988 & $\ldots$ \\
\hline
\end{tabular}

*(Utrilla-vázquez et al., 2020).

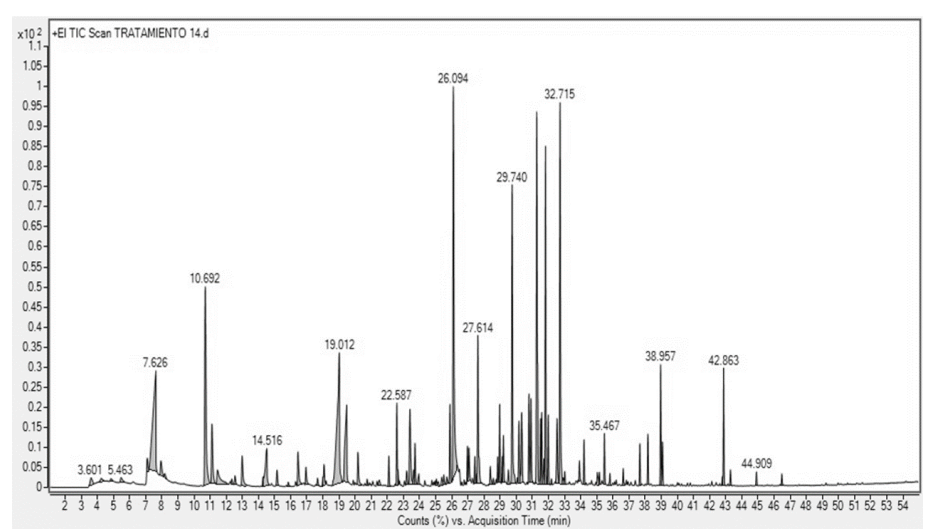

Figure 4. Chromatogram of volatile organic compounds precursors of the aroma of the T14 treatment.

Sixty-four volatile compounds were identified: 14 aldehydes and ketones; 7 pyrazines, 7 alcoholic compounds, 4 esters, 4 organic acids and other compounds, which confer the special notes to the cocoa samples (Rodríguez-Campos et al., 2012). At the end of fermentation, aldehydes and ketones represent the highest percentage of the total content of volatile compounds, which confer the pleasant notes of almond, butter or floral; pyrazines and alcohols are among the most important flavor groups of cocoa as they confer notes of chocolate, roasted coffee, fruity, floral, menthol, cinnamon, citrus and especially the Linalool volatile compound present in samples of cocoa from the Amazon region. Similar compounds were found in samples of Criollo and Trinitario cocoa grown in Chiapas, Mexico (Utrilla-Vázquez et al., 2020).

\section{Conclusions}

This study allowed to optimize the fermentation process of $T$. cacao native fine aroma, finding the optimal model. Emphasizing the importance of the fermentation process presented in the particular characteristics of the chemical composition and volatile compounds of native fine aroma cocoa from the Amazon region.

The microorganisms added in the fermentation process allowed accelerating a set of chemical reactions that give rise to the formation of flavor precursors and the formation of a qualitatively and quantitatively very important aroma precursor fraction, which was evidenced by the volatile compounds identified.

Regarding to the sensory analysis, a final maximum quality score of 71.1 was obtained, influencing the astringency due to the concentration of phenols, the bitterness due to the theobromine and caffeine content, and the special flavors and aromas due to the volatile compounds, especially from the aldehyde, ketone, ester, pyrazine and alcohol families, which confer these special notes to cocoa, allowing to have extraordinary samples.

\section{Funding source}

Instituto de Investigación para el Desarrollo Sustentable Ceja de Selva (INDES-CES) de la Universidad Nacional Toribio Rodríguez de Mendoza de Amazonas, through CINCACAO project / Contrato $\mathrm{N}^{\circ}$ 026-2016-FONDECYT: Círculo de Investigación para la Innovación y el Fortalecimiento de la Cadena de Valor del Cacao Nativo Fino de Aroma en la Zona Nor Oriental del Perú, fully financed the research work.

\section{Literature cited}

Afoakwa, E. O., Paterson, A., Fowler, M. \& Ryan, A. (2008). Flavor formation and character in cocoa and chocolate: a critical review. Critical reviews in food science and nutrition, 48(9), 840-857. https://doi. org/10.1080/10408390701719272

Brunetto, M., Gutiérrez, L., Delgado, Y., Gallignani, M., Zambrano, A., Gómez, A. \& Romero, C. (2007). Determination of theobromine, theophylline and caffeine in cocoa samples by a high-performance liquid chromatographic method with on-line sample cleanup in a switching-column system. Food Chemistry, 100(2), 459-467. https://doi.org/10.1016/j. foodchem.2005.10.007

Cardoso, P., Bezerra, V., Santos, A., Iúdice, J., Souza, J., Alburquerque, G. \& Barbosa, P. (2020). Determination of theobromine and caffeine in fermented and unfermented Amazonian cocoa (Theobroma cacao L.) beans using square wave voltammetry after chromatographic separation. Food Control. 108, 106887. https://doi.org/10.1016/j. foodcont.2019.106887

Castro-Alayo, E. M., Idrogo-Vásquez, G., Siche, R. \& Cardenas-Toro, F. P. (2019). Formation of aromatic compounds precursors during fermentation of Criollo and Forasterococoa. Heliyon, 5(1),e01157.https:// doi.org/10.1016/j.heliyon.2019.e01157

Cempaka, L., Aliwarga, L., Purwo, S., Kresnowati, P. \& Ari, M. T. (2014). Dynamics of Cocoa Bean Pulp Degradation during Cocoa Bean Fermentation: Effects of Yeast Starter Culture Addition. Journal of Mathematical \& Fundamental Sciences. https://doi.org/10.5614/j.math. fund.sci.2014.46.1.2

De Melo, G. V., Magalhães, K. T., de Almeida, E. G., Da Silva, I. \& Schwan, R. F. (2013). Spontaneous cocoa bean fermentation carried out in a novel-design stainless steel tank: Influence on the dynamics of microbial populations and physical-chemical properties. International journal of food microbiology, 161(2), 121-133. https://doi.org/10.1016/j. ijfoodmicro.2012.11.018

Gourieva, K. B. \& Tserevitinov, O. B. (1979). Methods for evaluating the degree of fermentation of cocoa beans. USSR Patent No. 646254646.

Haile, M. \& Kang, W. H. (2019). Antioxidant activity, total polyphenol, flavonoid and tannin contents of fermented green coffee beans with selected yeasts. Fermentation, 5(1), 29. https://doi.org/10.3390/ fermentation 5010029

Hernández-Hernández, C., López-Andrade, P. A., Ramírez-Guillermo, M. A., Guerra Ramirez, D. \& Caballero Perez, J. F. (2016). Evaluation of different fermentation processes for use by small cocoa growers in Mexico. Food science \& nutrition, 4(5), 690-695. https://doi.org/10.1002/fsn3.333

Jalil, A. M. M. \& Ismail, A. (2008). Polyphenols in cocoa and cocoa products: is there a link between antioxidant properties and health. Molecules, 13(9), 2190-2219. https://doi.org/10.3390/molecules13092190

John, W. A., Böttcher, N. L., Aßkamp, M., Bergounhou, A., Kumari, N., Ho, P. W. \& Ullrich, M. S. (2019). Forcing fermentation: Profiling proteins, peptides and polyphenols in lab-scale cocoa bean fermentation. Food chemistry, 278, 786-794. https://doi.org/10.1016/j.foodchem.2018.11.108

Kongor, J. E., Hinneh, M., Van de Walle, D., Afoakwa, E. O., Boeckx, P. \& Dewettinck, K. (2016). Factors influencing quality variation in cocoa (Theobroma cacao) bean flavour profile-A review. Food Research International, 82, 44-52. https://doi.org/10.1016/j.foodres.2016.01.012 


\section{8-8 $\mid$ Rev. Fac. Agron. (LUZ). 2022, 39(1): e223917. January - March. ISSN 2477-9407.}

Kresnowati, M. T. A. P., Suryani, L. \& Affifah, M. (2013). Improvement of cocoa beans fermentation by LAB starter addition. Journal of Medical and Bioengineering, 2(4). https://doi.org/10.12720/jomb.2.4.274-278

Murali, P. S., Venkateswarlu, G. \& Venkateswar, L. (2000). Effect of uracil on rifamycin SV production by Amycolatopsis mediterranei MV35R. Letters in applied microbiology, 31(1), 73-76. https://doi.org/10.1046/j.1472765x.2000.00769.x

León-Roque, N., Abderrahim, M., Nuñez-Alejos, L., Arribas, S. M. \& CondezoHoyos, L. (2016). Prediction of fermentation index of cocoa beans (Theobroma cacao L.) based on color measurement and artificial neural networks. Talanta, 161, 31-39. https://doi.org/10.1016/j. talanta.2016.08.022

Ooi, T. S., Ting, A. S. Y. \& Siow, L. F. (2020). Influence of selected native yeast starter cultures on the antioxidant activities, fermentation index and total soluble solids of Malaysia cocoa beans: A simulation study. LWT, 122, 108977. https://doi.org/10.1016/j.lwt.2019.108977

Pantelidis, G. E., Vasilakakis, M., Manganaris, G. A. \& Diamantidis, G. R. (2007). Antioxidant capacity, phenol, anthocyanin and ascorbic acid contents in raspberries, blackberries, red currants, gooseberries and Cornelian cherries. Food chemistry, 102(3), 777-783. https://doi.org/10.1016/j. foodchem.2006.06.021

Rodríguez-Campos, J., Escalona-Buendía, H. B., Contreras-Ramos, S. M., Orozco-Avila, I., Jaramillo-Flores, E. \& Lugo-Cervantes, E. (2012). Effect of fermentation time and drying temperature on volatile compounds in cocoa. Food chemistry, 132(1), 277-288. https://doi.org/10.1016/j. foodchem.2011.10.078
Sandhya, M. V. S., Yallappa, B. S., Varadaraj, M. C., Puranaik, J., Rao, L. J., Janardhan, P. \& Murthy, P. S. (2016). Inoculum of the starter consortia and interactive metabolic process in enhancing quality of cocoa bean (Theobroma cacao) fermentation. LWT-Food Science and Technology, 65, 731-738. https://doi.org/10.1016/j.lwt.2015.09.002

Senanayake, M., Jansz, E. R. \& Buckle, K. A. (1997). Effect of different mixing intervals on the fermentation of cocoa beans. Journal of the Science of Food and Agriculture, 74(1), 42-48. https://doi.org/10.1002/(SICI)10970010(199705)74:1<42::AID-JSFA768>3.0.CO;2-U

USAID, Equal Exchange y TCHO. (2018). Guía para la ficha de catación para el análisis sensorial de cacao. Disponible en https:/equalexchange.coop/ sites/default/files/Tasting-Guide_vF-JUNIO2018-ESP.pdf

Utrilla-Vázquez, M., Rodríguez-Campos, J., Avendaño-Arazate, C. H., Gschaedler, A. \& Lugo-Cervantes, E. (2020). Analysis of volatile compounds of five varieties of Maya cocoa during fermentation and drying processes by Venn diagram and PCA. Food Research International, 129, 108834. https://doi.org/10.1016/j.foodres.2019.108834

Wacher, M. C. (2011). Los microorganismos y el cacao. Revista digital universitaria, 12(4), 1067-6079. http://www.revista.unam.mx/vol.12/ num4/art42/\#a

Wollgast, J. \& Anklam, E. (2000). Polyphenols in chocolate: is there a contribution to human health. Food Research International, 33(6), 449-459. https:// doi.org/10.1016/S0963-9969(00)00069-7 